Article

\title{
Drought Assessment with the Community Land Model for 1951-2010 in East Asia
}

\author{
Myoung-Jin Um ${ }^{1}$ (D), Mun Mo Kim ${ }^{2}$, Yeonjoo Kim ${ }^{1}$ and Daeryong Park ${ }^{3, *(D)}$ \\ 1 Department of Civil and Environmental Engineering, Yonsei University, Seoul 03722, Korea; \\ movie21@yonsei.ac.kr (M.-J.U.); yeonjoo.kim@yonsei.ac.kr (Y.K.) \\ 2 Department of Civil Engineering, Shingu University, Seongnam-si, Gyeonggi-do 13174, Korea; \\ munmo310@shingu.ac.kr \\ 3 Department of Civil and Environmental Engineering, Konkuk University, Seoul 05029, Korea \\ * Correspondence: drpark@konkuk.ac.kr; Tel.: +82-2-450-0493
}

Received: 2 May 2018; Accepted: 15 June 2018; Published: 20 June 2018

check for updates

\begin{abstract}
Severe droughts have occurred in East Asia; however, observational hydroclimate data that covers the entire region is lacking. The objective of this study is to investigate drought assessment in East Asia. This study estimated three drought indices by generating hydroclimate variables using the Community Land Model (CLM). The results of the CLM were verified by comparison with Climatic Research Unit (CRU) data for precipitation and air temperature and the Global Runoff Data Centre (GRDC) data for runoff. Spatial and temporal variations in three drought severity indices, including the standardized precipitation evapotranspiration index (SPEI), the standardized runoff index (SRI), and the Standardized Soil Moisture Index (SSMI), in East Asia were estimated using the CLM output and compared with the SPEI in the CRU. This study classified drought frequency into four classes depending on the drought severity with 5-deg gapped longitude and latitude for 1951-2010 in East Asia and found that moderately dry (D2) and severely dry (D3) drought frequency classes matched well between the CLM and CRU data. The SPEI in the CLM and CRU data showed very similar frequency magnitudes and an increasing temporal trend. The SRI and SSMI frequencies for CLM also showed an increasing temporal trend compared to the SPEI frequency trend. The results of this study show that CLM outputs are reliable for drought analysis in East Asia. Furthermore, this study suggests the possibility of CLM application to other regions to generate hydroclimate data that is otherwise insufficient.
\end{abstract}

Keywords: climate research unit; Community Land Model; drought severity index; East Asia

\section{Introduction}

A drought is defined as a period in which a particular variable, such as precipitation, soil water, or runoff amounts, exhibits lower-than-average levels in a specific region, resulting in widespread economic, environmental, and social impacts [1-3]. To evaluate droughts, various drought indices have been suggested. The standardized precipitation index (SPI) $[4,5]$ calculates the normalized long-term precipitation to evaluate the class of droughts. Vicente-Serrano et al. [6] suggested the standardized precipitation evapotranspiration index (SPEI), which is calculated using a combination of the water balance and cumulative water deficit and the adjusted log-logistic probability distribution [7]. The standardized runoff index (SRI) is used to express hydrological droughts [8] and requires runoff datasets. To study agricultural droughts, a standardized soil water index (SSWI) was suggested. Both SRI and SSWI have been applied to droughts in the United States with the SWAT model [9] and in China with the Variable Infiltration Capacity (VIC) model [10]. 
Droughts of various magnitudes often occur in East Asia. Alongside floods, they are strongly correlated with the East Asian monsoonal circulation, characterized by strong southerly and northerly winds in the summer and winter, respectively [11]. Unusual and severe droughts occurred in areas of East Asia, including China [12] and South Korea [13] between 2013 and 2015, where severe drought resulted in a shortage of water resources. There have been many studies on drought analysis in China [14-20] and Korea [21-24] that used various drought indices, including the Palmer drought severity index (PDSI), SPI, and SPEI. However, droughts in the East Asia region have rarely been studied [11,24-26]. Min et al. [25] investigated drought occurrence and intensity in Korea and East Asia. They estimated SPI from the Climatic Research Unit (CRU) dataset and proposed that the SPIs for eastern China were highly correlated with those for Korea for 1951-1992. Zhang and Zhou [11] investigated droughts in East Asia (China, Korea, Japan, and Mongolia) using the Global Precipitation Climatology Project data from 1979 to 2012 and the CRU data from 1950 to 2009. They applied two drought indices: a self-calibrating PDSI and the standardized precipitation index (SPI). They suggested that drought variations in East Asia are strongly correlated with monsoonal circulation. Um et al. [24] compared the Moderate Resolution Imaging Spectroradiometer (MODIS)-based drought severity index (DSI) with the DSI-incorporated Advanced Very High-Resolution Radiometer-derived normalized difference vegetation index (DSI $\mathrm{AVHRR}_{\mathrm{A}}$ ) and SPEI with CRU dataset in East Asia. They suggested the possible use of DSI based on the combined products of the normalized difference vegetation index (NDVI) and the revised drought classification to match the results between SPEI and DSI.

The Community Land Model (CLM) is based on a land-surface scheme and part of the Community Earth System Model (CESM), and is widely applied to simulate land-surface processes on regional and global scales and provide reliable outputs for various ecosystems and cropping systems [27-34]. The CLM is mainly used to simulate the biophysical ecosystem processes. Recently, some studies have applied CLM to drought analysis on a regional scale [35-37]. However, most studies have investigated the droughts in East Asia using observed datasets with limitations to climate variables, such as precipitation and temperature. Moreover, previous studies have focused on the spatial (or regional) and temporal (or long-term) trends of drought indices.

The main objective of this study is to evaluate the applicability of the CLM on the droughts in East Asia. The specific objectives are (1) to compare the drought indices between the observed and CLM data to verify the CLM results, (2) to generate and analyze other drought indices such as the SRI and SSMI for East Asia using the verified CLM with the observed CRU dataset, and (3) to estimate other drought indices using the CLM and compare the characteristics of different drought indices for East Asia. This study used the CRU dataset as the observed data. The CRU data and the CLM are described in Sections 2.1 and 2.2, respectively.

\section{Materials and Methods}

\subsection{Study Area and Dataset}

We evaluated meteorological, hydrological, and agricultural droughts using the observations and simulations for 1951-2010 in the area of East Asia that lies between $64-174^{\circ} \mathrm{E}$ and $0-65^{\circ} \mathrm{N}$. We chose the CRU dataset as the observational dataset and utilized one dataset simulated by the CLM to assess the statistical droughts for the study period.

The CRU dataset is one of the most popular observational datasets, frequently used to analyze the historical climate of the world (Table 1). The CRU dataset is the combination of many datasets from sources such as the World Meteorological Organization (WMO) and the United States National Oceanographic and Atmospheric Administration (NOAA, via its National Climatic Data Center, NCDC); it is constructed by the climate anomaly method (CAM) [38]. Harris et al. [39] provided a CRU dataset with high spatial resolution $\left(0.5^{\circ} \times 0.5^{\circ}\right.$ longitude-latitude) for monthly precipitation (PR), temperature (TA), and potential evapotranspiration (PET) for 1901-2015; we used the data for 1951-2010 in this study. Monthly PR and TA data in the CRU are based on observations, but monthly 
PET data are derived from several variables, including PR, TA, and a fixed monthly wind speed dataset [39].

Table 1. Description of the observations for drought analysis.

\begin{tabular}{ccccc}
\hline Model & Description & Resolution & Period & Variable \\
\hline \multirow{2}{*}{ CRU } & Climate research unit & $0.5^{\circ}$ & & PR \\
& Version: TS v.4.00 & Monthly & 1951-2010 & TA \\
& (Harris et al., 2014 [39]) & & PET \\
\hline
\end{tabular}

We also used the Global Runoff Data Centre (GRDC) dataset (http:/ / www.compositerunoff.sr. unh.edu), which is a spatial composite runoff dataset of river discharge observations and water balance model simulations [40], to compare the simulated runoff datasets by the CLM. However, the GRDC dataset only has fixed forms, e.g., the monthly average and annual average runoff with a 30-min resolution for 1986-1995.

\subsection{Community Land Model}

The early development of the CLM was started by the National Center for Atmospheric Research (NCAR) to extend the Land Surface Model (LSM), which simulates the exchange of surface water and energy fluxes at the soil-atmosphere interface, to include the carbon cycle, vegetation dynamics, and channel routing [41]. The CLM, a land surface model, is the land module applied in the CESM, also known as the Community Climate System Model (CCSM) [42,43]. CLM has been used to simulate the biophysical processes on the land surface of the Weather Research and Forecasting (WRF) model [44]. CLM4 extensively improves the snow depth/melt process, runoff simulation, soil hydrology thermodynamics, and albedo parameters [33]. CLM4 has been widely applied, and its performance has been verified in many studies [33,45-48]. TOPMODEL [49] is currently used as the basic runoff formulation of CLM [50,51]. Table 2 shows the appropriate climate regions and runoff process assumptions of the CLM incorporating the TOPMODEL scheme. TOPMODEL has the following assumptions: (1) the dynamical relationship in the groundwater layer is assumed to be the continuous steady state; (2) the rate at which the groundwater level change in a watershed is constant; (3) the hydraulic gradient in the groundwater layer is assumed to be equal to the surface gradient; and (4) the distribution of the permeability coefficient to the downstream is assumed to be an exponential function of the groundwater deficit or the depth of groundwater table [46,49]. With these assumptions, TOPMODEL is properly simulated for humid climates or mountainous areas where surface saturation leads directly to surface runoff.

Table 2. Summary of the runoff processes in the CLM [52].

\begin{tabular}{|c|c|}
\hline Classification & Description \\
\hline Model & CLM \\
\hline Version & CLM4.0 \\
\hline Soil Hydrology Scheme & TOPMODEL \\
\hline $\begin{array}{l}\text { Assumption. } \\
\text { (Surface and subsurface } \\
\text { runoff processes) }\end{array}$ & $\begin{array}{l}\text { (1) The successive steady states for the saturated zone dynamics. } \\
\text { (2) The homogeneous recharge rate to the water table over a catchment. } \\
\text { (3) Using the local surface slope for the hydraulic gradient of the saturated zone. } \\
\text { (4) An exponential function of storage deficit or depth to the water table is used } \\
\text { for the distribution of downslope transmissivity. }\end{array}$ \\
\hline $\begin{array}{l}\text { Recommended } \\
\text { climate condition }\end{array}$ & Humid climate and mountainous areas where exist a shallow groundwater table \\
\hline
\end{tabular}


For input data in the CLM, this study adopted the precipitation and air temperature data in the CRU-NCEP dataset. The CRU-NCEP dataset is a combination of the CRU monthly climatology data with a 0.5 -deg resolution from 1901 to 2009 and the NCEP reanalysis data with a 2.5-deg resolution from 1948 to 2013. The CRU-NCEP dataset combines the advantages of NCEP's temporal and CRU's spatial resolutions. The full dataset is spatially and temporally downscaled by the linear interpolation method [53]. Therefore, the CRU-NCEP data has 0.5-deg resolutions and 6-h timesteps before further data. The target period of this study was between 1951 and 2010.

\subsection{Quantifying Drought Risk}

In this study, three types of droughts are defined using three statistical drought indices (SPEI, SRI, and SSMI) with four natural variables: precipitation (PR) and potential evaporation (PET) for meteorological droughts, runoff (R) for hydrological droughts, and soil moisture (SM) for agricultural droughts.

\subsubsection{Meteorological Drought}

Three indices, SPI, SPEI, and PDSI, are typically used to quantify meteorological droughts. SPI $[4,54]$ only uses precipitation data to calculate water deficit, whereas SPEI [6] uses both precipitation and evaporation data to quantify drought severity. PDSI [55] estimation is more complex because this index requires four inputs, such as temperature, precipitation, location information, and available water capacity [56]. In this study, we chose SPEI to quantify the meteorological drought because the CRU dataset provides precipitation and potential evaporation data; the CLM also provides precipitation data directly as well as potential evaporation data with additional analysis. SPEI [6] is estimated using the monthly water deficit (D) in Equation (1) and the three-parameter log-logistic distribution in Equation (5):

$$
D=P R-P E T,
$$

where $D$ is the monthly water deficit, $P R$ is the monthly precipitation, and $P E T$ represents the monthly potential evaporation data. In this study, the daily PET data for CLM were obtained from Penman [57] and Donohue et al. [58] using Equation (2) and cumulated to monthly values:

$$
P E T=\frac{\Delta}{\Delta+\gamma} R_{n}+\frac{\gamma}{\Delta+\gamma} \frac{6430\left(1+0.536 u_{2}\right) e}{\lambda}
$$

where $\Delta$ is the slope of the saturation vapor pressure curve, $\gamma$ is the psychrometric constant, $R_{n}$ is the daily net radiation, $u_{2}$ is the daily average wind speed at $2-m$ height, $e$ is the vapor pressure deficit, and $\lambda$ is the latent heat of water evaporation. The cumulative difference $X_{i, j}^{k}$ over timescale $k$ in a given month $j$ and year $i$ is calculated as given by [26]:

$$
\begin{gathered}
X_{i, j}^{k}=\sum_{l=13-k+j}^{12} D_{i-1, l}+\sum_{l=1}^{j} D_{i, l} \text { for } j<k \\
X_{i, j}^{k}=\sum_{l=j-k+1}^{j} D_{i, l} \text { for } j \geq k .
\end{gathered}
$$

The cumulative probability distribution function of the $D$ series is as follows [26]:

$$
F(X)=\left[1+\left(\frac{\alpha}{x-\mu}\right)^{\beta}\right]^{-1}
$$


where $F(X)$ is the cumulative density function of a three-parameter log-logistic distribution for the monthly water deficit, $D$, and $\alpha, \beta$, and $\mu$ are scale, shape, and origin parameters, respectively. Finally, SPEI is estimated as follows [6]:

$$
\mathrm{SPEI}=\mathrm{W}-\frac{2.515517+0.802853 W+0.010328 W^{2}}{1+1.432788 W+0.189269 W^{2}+0.001308 W^{3}}
$$

where, $\mathrm{W}=\sqrt{-2 \ln (P)}$ for $P \leq 0.5, \mathrm{~W}=\sqrt{-2 \ln (1-P)}$ for $P \geq 0.5$, and $P$ is the probability of exceeding a determined $D$ value $(P=1-F(X))$.

\subsubsection{Agricultural and Hydrological Drought}

Meteorological droughts usually propagate hydrological droughts (which are related to runoff, streamflow, and groundwater flow), and agricultural droughts, which are related to soil moisture. The water deficit generally begins with a lack of precipitation and moves to insufficient runoff, soil moisture, streamflow, and groundwater with some time lag in between each impact [59]. In this study, we used the runoff and soil moisture data simulated by the CLM to estimate the agricultural and hydrological droughts; these two variables are used to calculate each drought index (i.e., SSMI from soil moisture data and SRI from runoff data) with procedures similar to those used to estimate SPI [9]. This estimation procedure consists of standardization, accumulation, and the application of a gamma distribution $[9,60,61]$.

\subsection{Assessment of Drought in CLM}

We assessed how much the three statistical drought indices, calculated using CLM data, can capture the historical drought observations (CRU data). First, the boundary datasets, such as precipitation and air temperature, and potential evaporation datasets from the CLM were compared with the CRU dataset for spatial and temporal distributions across the five latitude ranges. Second, runoff datasets from the CLM were compared with the GRDC dataset for 1986-1995. Finally, the soil moisture datasets from the CLM were generated since the observational data is incomplete in the study period. For example, the observed soil moisture data in MetOp/ ASCAT only exists since 2007, and their availability is limited. Consequently, we estimated the drought indices (SPEI, SRI, and SSMI) for East Asia for 1951-2010 and compared them with the CRU and CLM data with the spatiotemporal characteristics considered (Table 3).

Table 3. Classification of dryness status.

\begin{tabular}{ccc}
\hline Category & Description & Drought Index (SPEI, SRI, and SSMI) \\
\hline D1 & Incipient and mild dry & $\leq-0.0$ \\
D2 & Moderate dry & $\leq-1.0$ \\
D3 & Severe dry & $\leq-1.5$ \\
D4 & Extremely dry & $\leq-2.0$ \\
\hline
\end{tabular}

\section{Results and Discussion}

This study quantified the accuracy of the CLM in predicting the observed meteorological drought data and investigated the propagation of meteorological droughts in the CLM to hydrological and agricultural droughts for 1951-2010 in East Asia. First, we investigated the variations in input variables (precipitation and air temperature) to estimate the drought indices (Section 3.1). Second, the spatiotemporal variations in drought indices calculated using the CRU and CLM data were analyzed, and the similarities among the drought indices and changes in the indices with time were investigated in Section 3.2. 


\subsection{Regional Variations of Input Variables for Drought Indices}

We investigated the spatiotemporal variations in five input variables-precipitation (PR), air temperature (TA), potential evapotranspiration (PET), runoff, and soil moisture (SM) —and in three drought indices in East Asia for 1951-2010. The PR and TA datasets in CRU were used to estimate SPEI, and those in CRU-NCEP were used to run the CLM. PET data in CRU were estimated based on observations [39], and those in the CLM were calculated using simulation results and Equation (3). The runoff and SM datasets are the simulation results from CLM.

Figures 1 and 2 show the spatial distribution and temporal variations of the annual latitude-dependent PR and TA analyzed using the CRU and CRU-NCEP datasets. The annual average PR data in the CRU (CRU-NCEP) data changed from 334.1 (303.8) $\mathrm{mm}$ at the latitude range of 40-45 to $2886.2(2802.8) \mathrm{mm}$ at the latitude range of $5-10^{\circ}$; the annual average PR data at $0-60^{\circ}$ in CRU and CRU-NCEP were 706.9 and $663.2 \mathrm{~mm}$, respectively. The monthly average PR data in the CRU and CRU-NCEP datasets varied from 21.78 and $19.80 \mathrm{~mm}$ in February to 119.30 and $115.10 \mathrm{~mm}$ in July, respectively. The annual average TA data in the CRU (CRU-NCEP) dataset changed from -8.69 $(-12.11){ }^{\circ} \mathrm{C}$ at $60-65^{\circ}$ to $26.48(26.85){ }^{\circ} \mathrm{C}$ at $10-15^{\circ}$ the annual average TA data at $0-60^{\circ}$ in the CRU and CRU-NCEP datasets were 5.23 and $3.66^{\circ} \mathrm{C}$, respectively. The monthly average TA data in CRU and CRU-NCEP varied from -10.74 and $-13.59^{\circ} \mathrm{C}$ in January to 19.66 and $19.19^{\circ} \mathrm{C}$ in July, respectively. The spatiotemporal trends in PR and TA in the CRU and CRU-NCEP datasets were similar to each other despite small differences.

The potential evapotranspiration (PET) datasets, which include daily net radiation, daily average wind speed at 2-m height, and relative humidity data, were used to estimate SPEI. We investigated the spatial and temporal distributions of the latitude-dependent annual average PET data (Figure 3) and monthly average PET data (Figure 4). The maximum annual average PET in CRU and CLM were $1413.0 \mathrm{~mm}$ at $15-20^{\circ}$ and $2466.2 \mathrm{~mm}$ at $10-15^{\circ}$, respectively. The minimum annual average PET in CRU and CLM was 409.5 and $681.2 \mathrm{~mm}$ at $60-65^{\circ}$, respectively. The annual average PET values at $0-60^{\circ}$ in CRU and CLM were 841.8 and $1360.9 \mathrm{~mm}$, respectively. The monthly average PET values in CRU and CLM were $1.40 \mathrm{~mm}$ in January, -5.18 and $-4.71 \mathrm{~mm}$ in November, and 98.51 and $180.91 \mathrm{~mm}$ in July, respectively. There were similar spatiotemporal trends in the two datasets, but there were differences between the PET data in the CRU and CLM datasets. These differences occurred due to PET data creation conditions because the PET data in CRU are estimated based on several limiting assumptions and observed data. PET in the CLM, however, is only estimated by the hydroclimate equations.

The annual and monthly average runoff datasets in GRDC are estimated based only on observations [40] for 1986-1995. However, the monthly runoff time series were not available, and we could only compare the general statistical characteristics of the two datasets. We investigated the latitude-dependent spatial and temporal distribution of annual average runoff data for 1986-1995 (Figure 5) and also estimated the monthly average runoff (Figure 6) for 1986-1995. The annual average runoff data in the GRDC and CLM datasets changed from 85.3 and $47.6 \mathrm{~mm}$ at $45-50^{\circ}$ to $333.1 \mathrm{~mm}$ at $60-65^{\circ}$ and $1491.3,1409.2$, and $1965.5 \mathrm{~mm}$ at $0-5^{\circ}$. The annual average runoff values at $0-60^{\circ}$ in GRDC and CLM were 322.8, 202.9, and $602.6 \mathrm{~mm}$, respectively. The monthly average runoff values in GRDC and CLM varied from 4.49, 6.26, and $28.00 \mathrm{~mm}$ in February to 45.87 and $25.43 \mathrm{~mm}$ in August and $73.30 \mathrm{~mm}$ in May, respectively. The spatiotemporal trends were similar among the three datasets: runoff values became lower at higher latitudes, and summer runoff values were higher than those in other seasons. However, the range of spatial and temporal variations was different for these three datasets. 

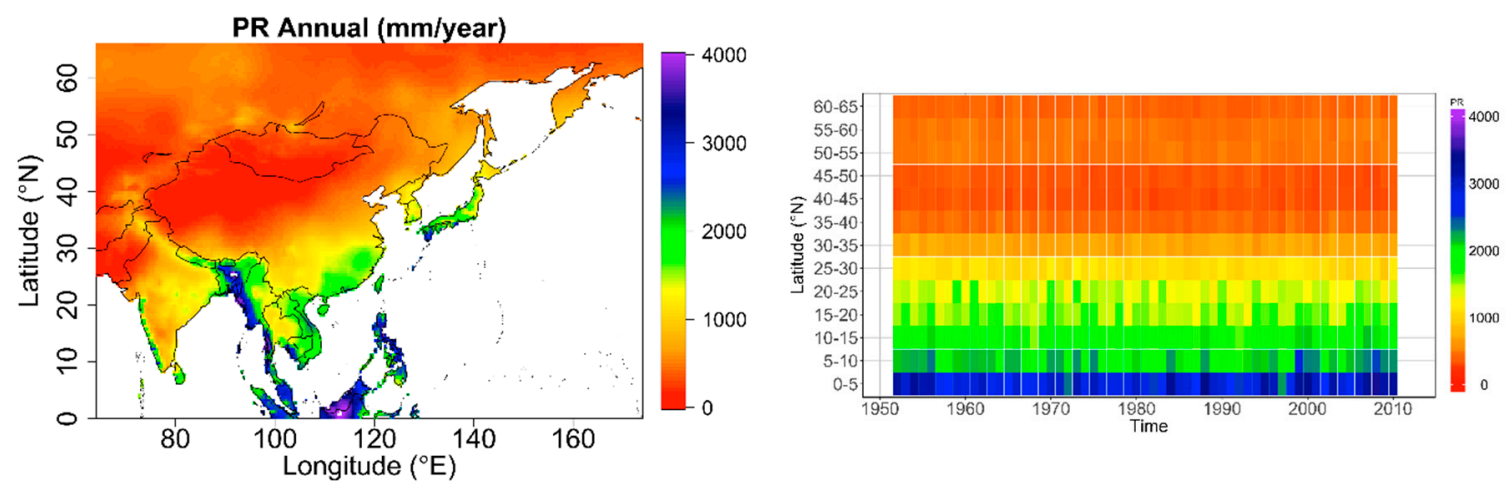

(a1) CRU
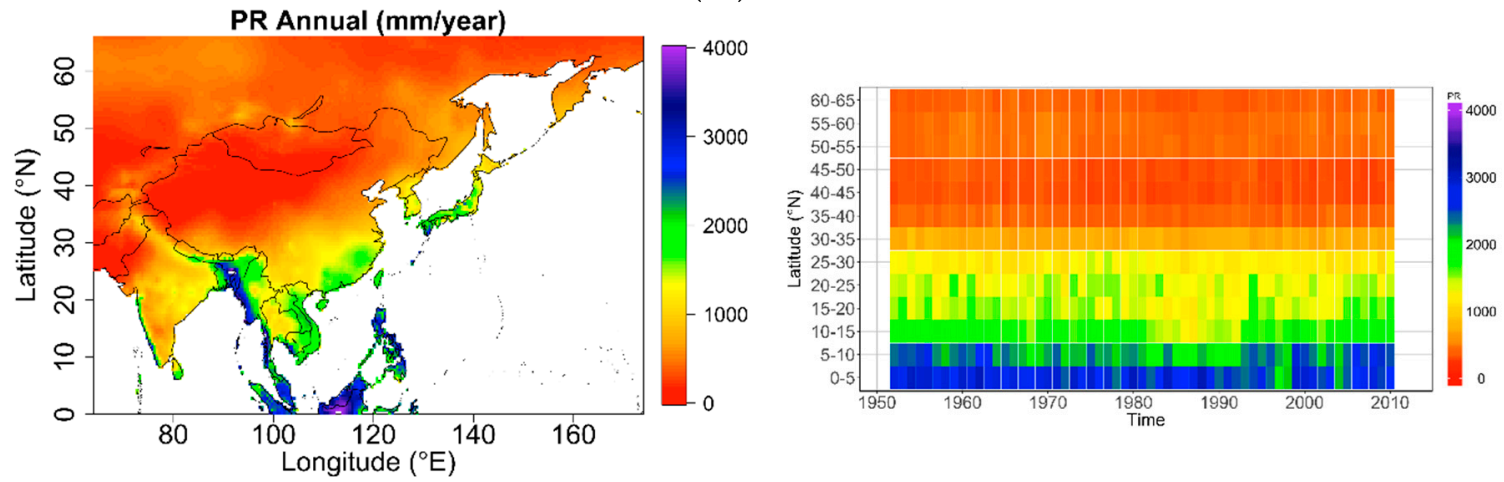

(a2) CRU-NCEP

(a) Spatiotemporal annual precipitation

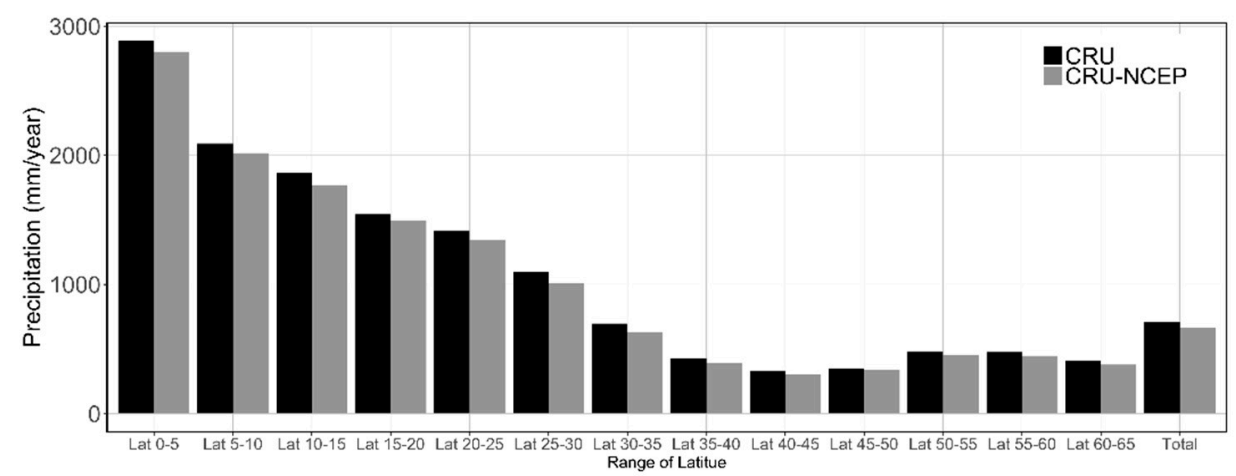

(b) Latitude-dependent annual precipitation

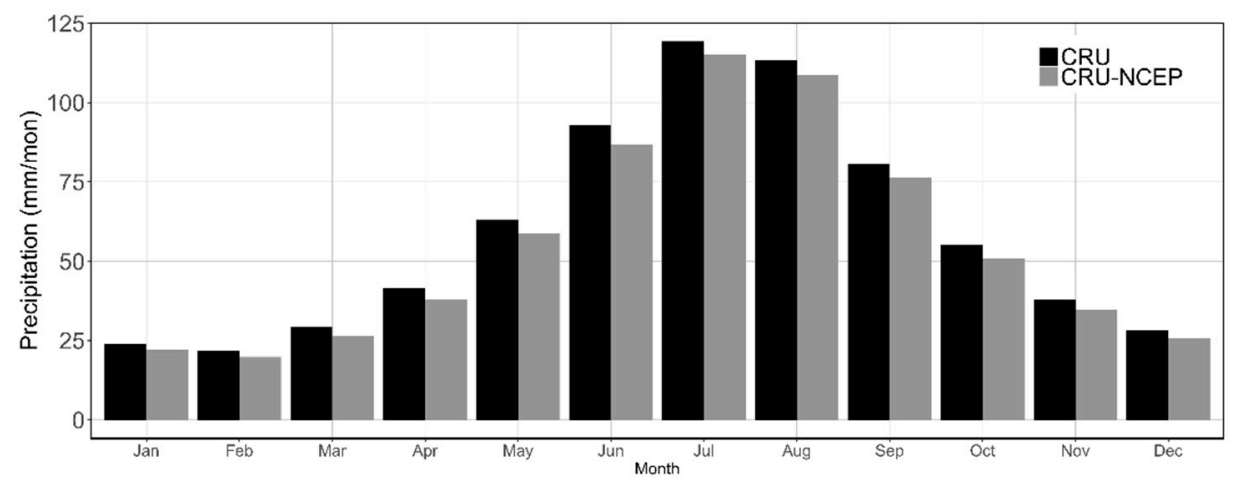

(c) Monthly average precipitation

Figure 1. Precipitation for 1951-2010 in East Asia. 

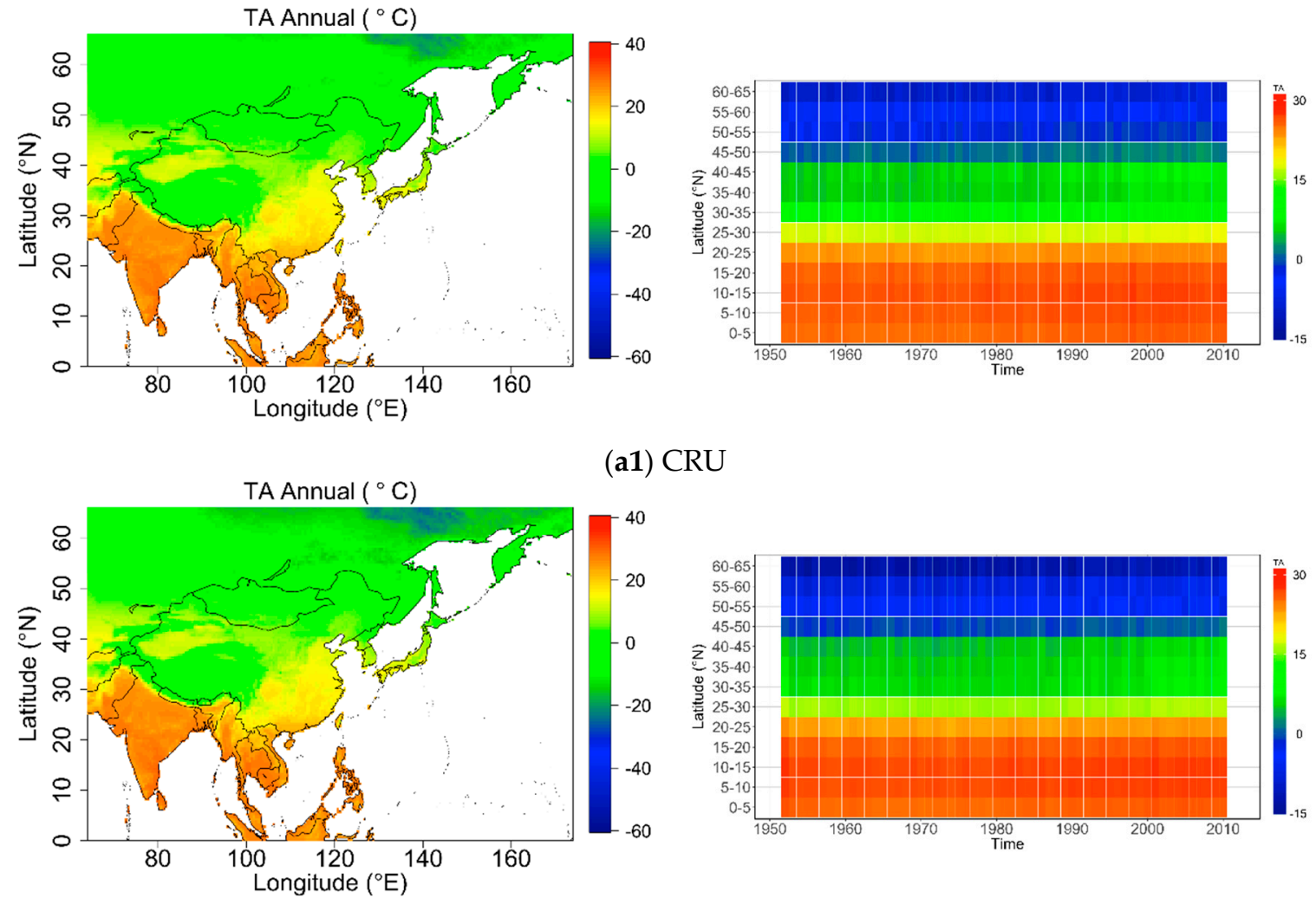

(a1) CRU

(a2) CRU-NCEP

(a) Spatiotemporal annual average temperature

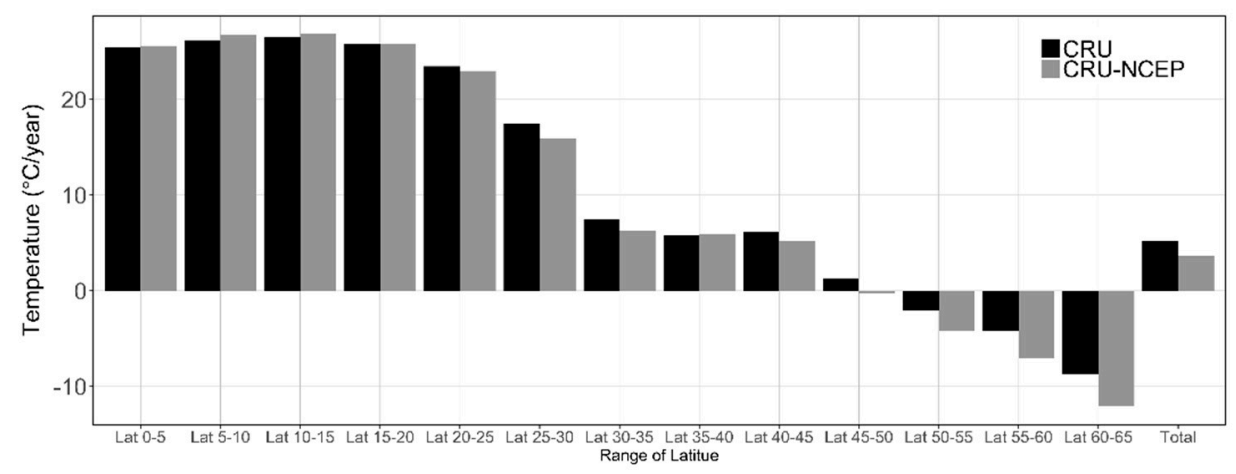

(b) Latitude-dependent annual average temperature

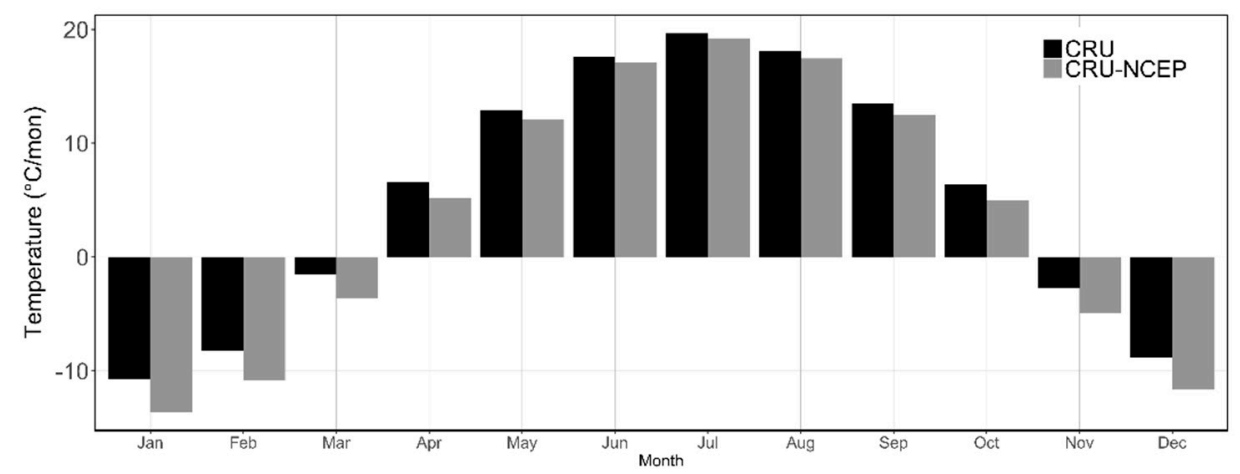

(c) Monthly average temperature

Figure 2. Temperature for 1951-2010 in East Asia. 

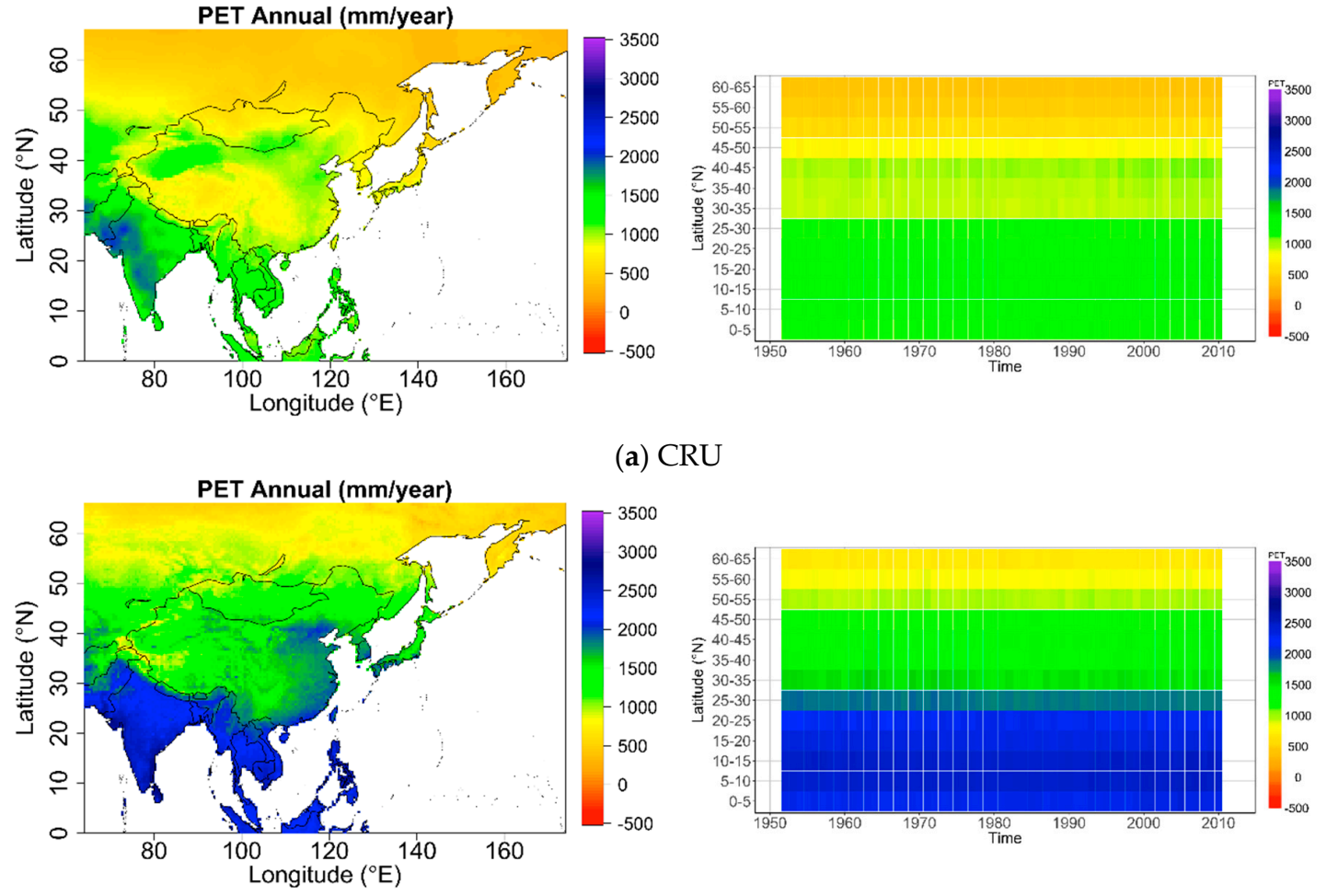

(a) CRU
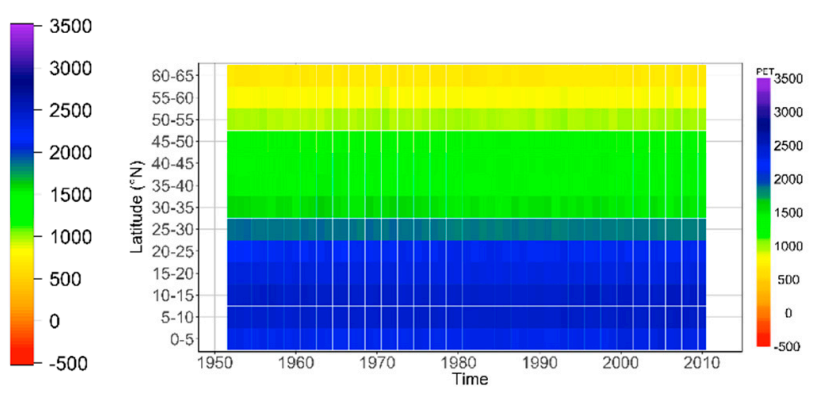

(b) CLM

Figure 3. Spatiotemporal annual evapotranspiration for 1951-2010 in East Asia.

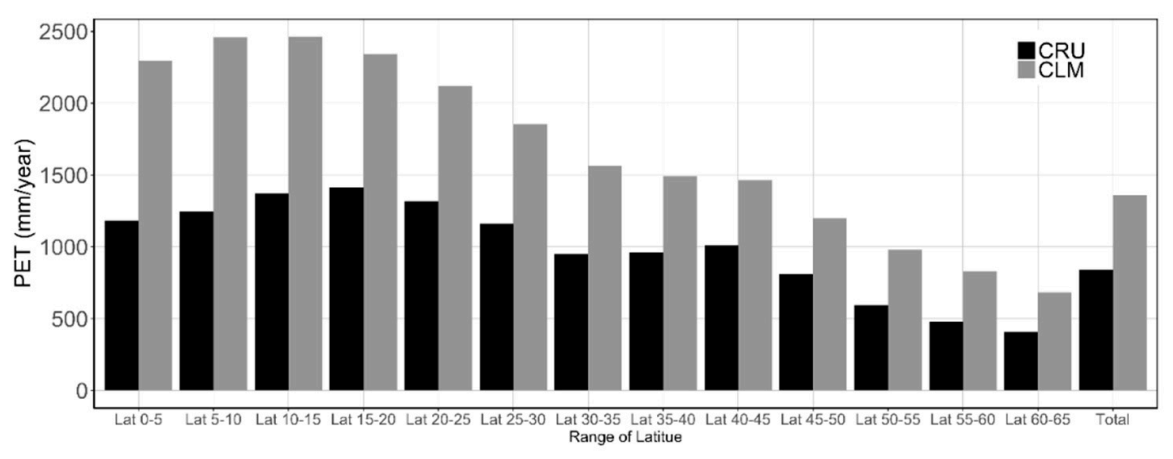

(a) Latitude-dependent annual average potential evapotranspiration

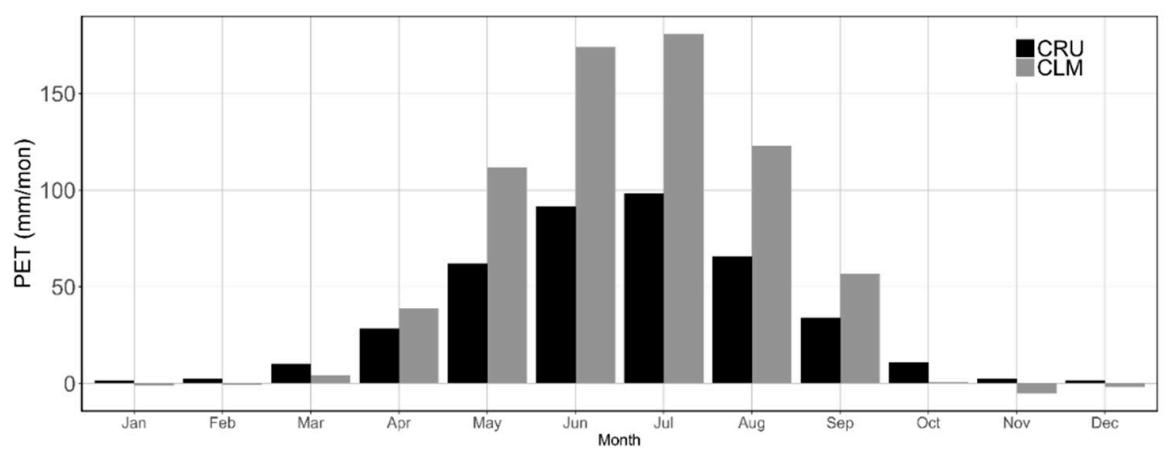

(b) Monthly average potential evapotranspiration

Figure 4. Annual and monthly potential evapotranspiration for 1951-2010 in East Asia. 

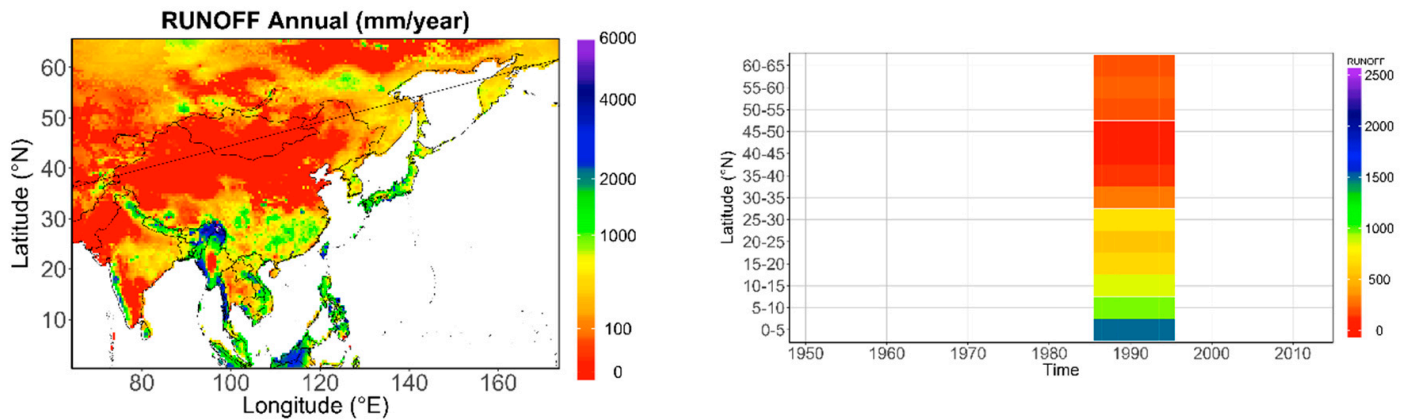

(a) GRDC (1986-1995)
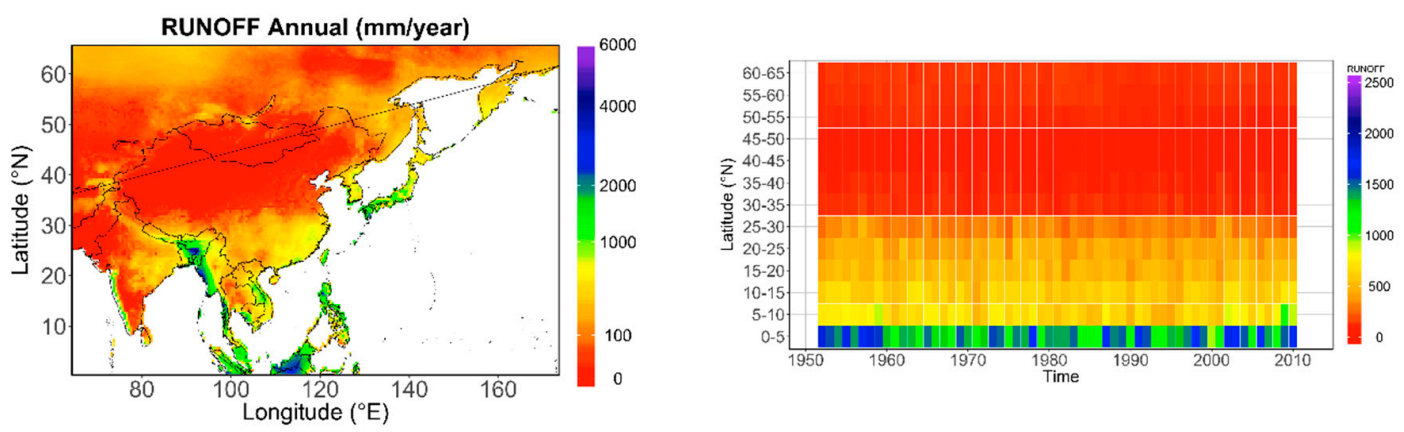

(b) CLM (1986-1995)

Figure 5. Spatiotemporal annual runoff in East Asia (1986-1995).

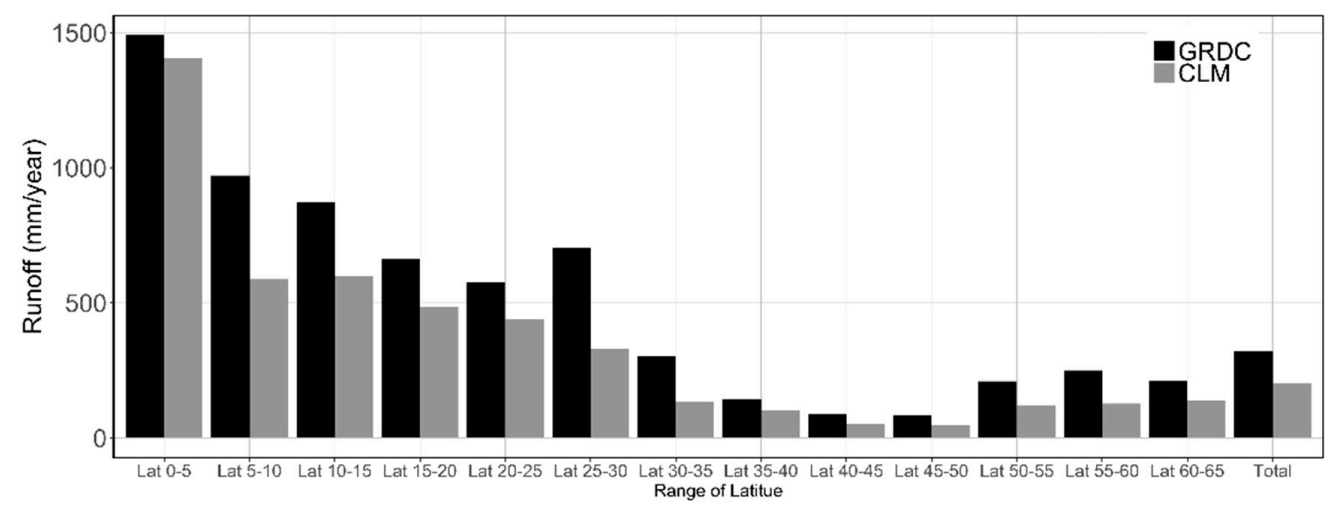

(a) Latitude-dependent annual average runoff

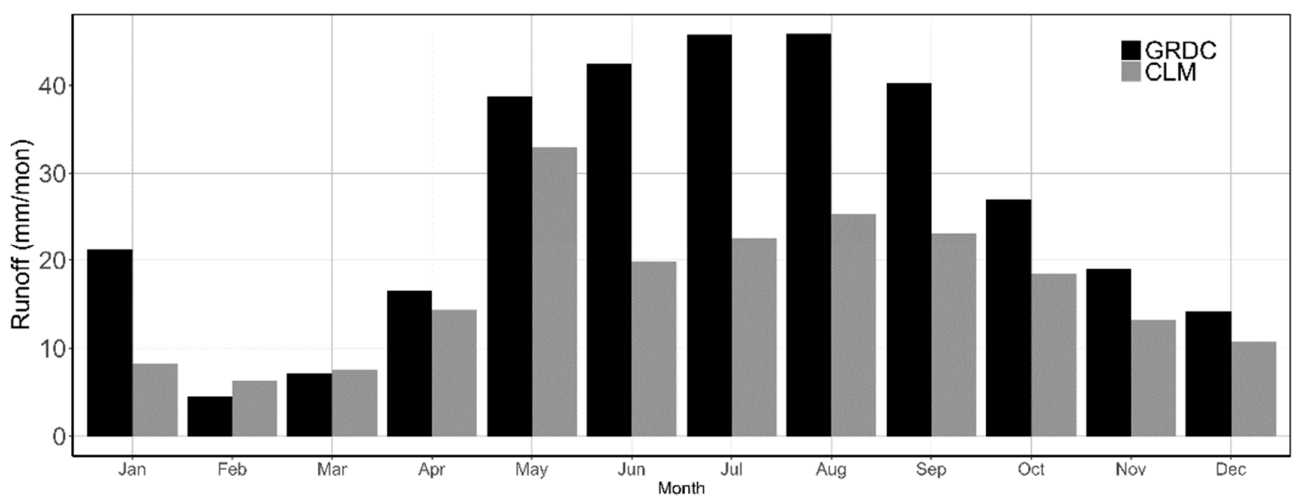

(b) Monthly average runoff

Figure 6. Annual and monthly runoff for 1986-1995 in East Asia. 
Soil moisture (SM) data is usually collected on-site, and there are only a few global-scale studies on soil moisture data [62-64]. Spatiotemporal observations for SM are not currently available, because the satellite-based soil observation dataset is not as long as the study period (1951-2010). Therefore, we only used the CLM simulation dataset for East Asia for 1951-2010. The spatiotemporal variations of the latitude-dependent annual average SM data are shown in Figure 7, and the estimated annual average and monthly average SM data are presented in Figure 8.
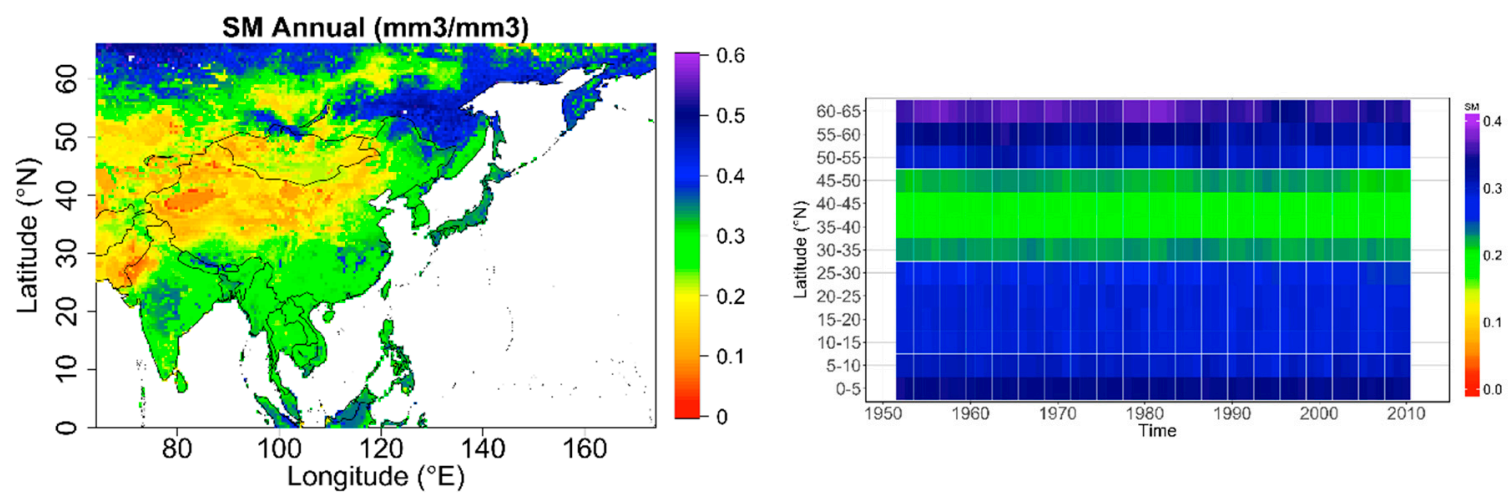

Figure 7. Spatiotemporal annual soil moisture content for 1951-2010 in East Asia.

The annual average SM values in CLM changed from $0.187 \mathrm{~m}^{3} / \mathrm{m}^{3}$ at $35-40^{\circ}$ to $0.359 \mathrm{~m}^{3} / \mathrm{m}^{3}$ at $60-65^{\circ}$ and $0.288 \mathrm{~m}^{3} / \mathrm{m}^{3}$ at $0-5^{\circ}$, and the annual average runoff at $0-60^{\circ}$ in CLM was $0.272 \mathrm{~m}^{3} / \mathrm{m}^{3}$. The monthly average SM values in CLM varied from $0.2704 \mathrm{~m}^{3} / \mathrm{m}^{3}$ in February and $0.2008 \mathrm{~m}^{3} / \mathrm{m}^{3}$ in July to $0.2747 \mathrm{~m}^{3} / \mathrm{m}^{3}$ in May and $0.2087 \mathrm{~m}^{3} / \mathrm{m}^{3}$ in October, respectively. The annual average SM values were lower around latitude $35-40^{\circ}$ but higher at latitudes greater than $50^{\circ}$.

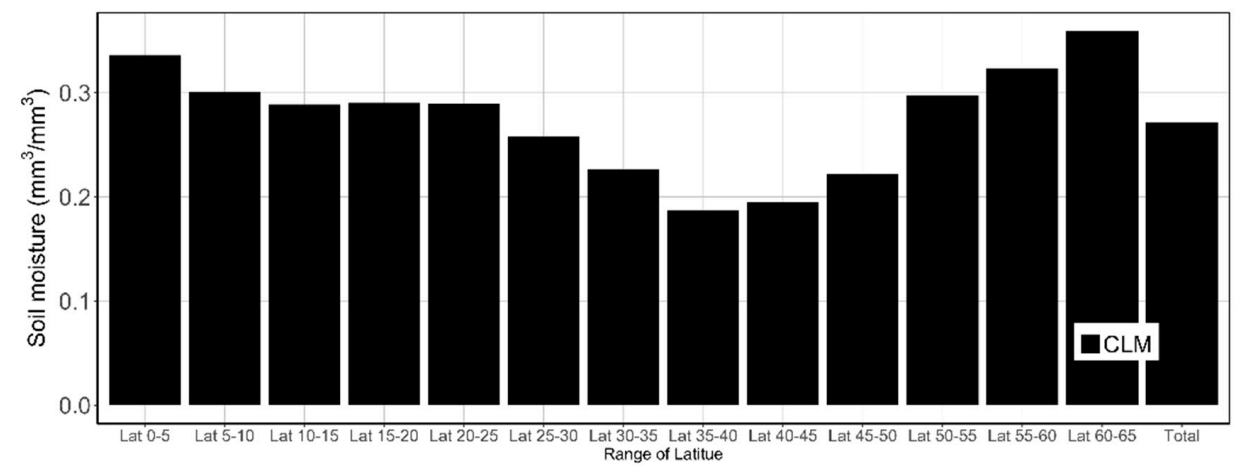

(a) Latitude-dependent annual average soil moisture

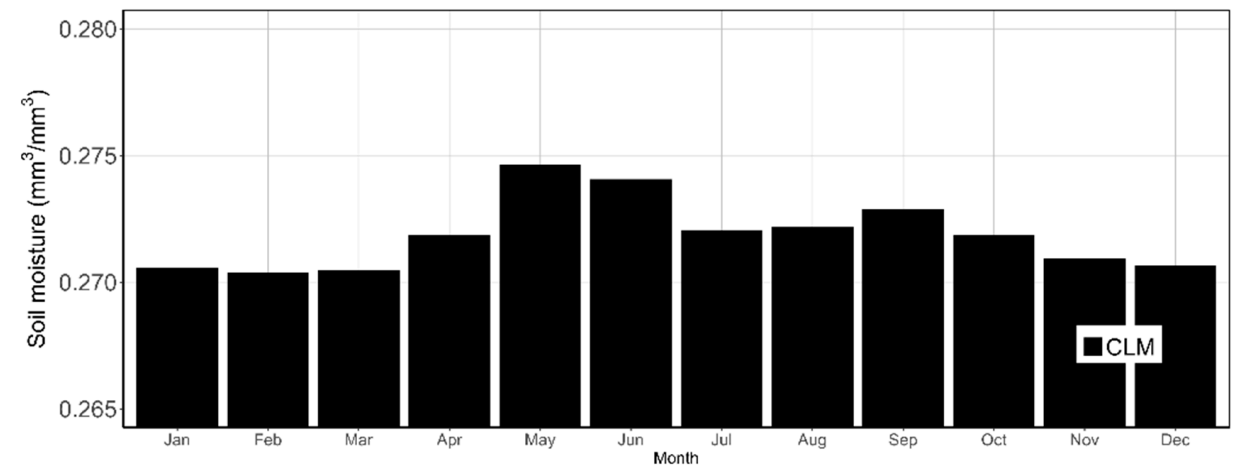

(b) Monthly average soil moisture

Figure 8. Annual and monthly soil moisture content for 1951-2010 in East Asia. 


\subsection{Spatiotemporal Variations of Droughts}

We used four variables (precipitation, potential evapotranspiration, runoff, and soil moisture) in Section 3.1 to estimate three drought indices (SPEI, SRI, and SSMI) for 1951-2010 in East Asia. We selected a 12-month lag to investigate the annual variations in the meteorological (SPEI), hydrological (SRI), and agricultural (SSMI) drought systems. These three drought indices were estimated using the methods described in Sections 2.3.1 and 2.3.2. We presented the spatial drought characteristics in Figures 9-11 and the temporal movements in Figures 12 and 13.

We first analyzed and compared the spatial distributions of the three drought indices for three datasets. One of the most severe droughts in East Asia occurred in 2009 [11,65]. SPEI calculated using the observations (CRU) shows the broad and severe drought status (Figure 9(a1)), and SPEIs estimated by the CLM simulations displayed similar spatial patterns (Figure 9(b1)).

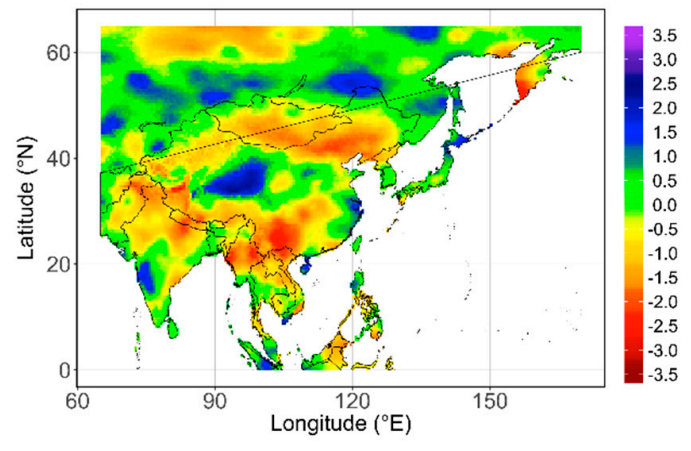

(a1) SPEI12

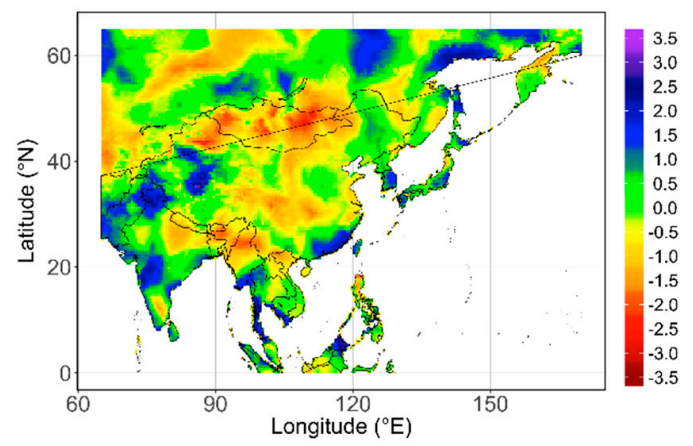

(b1) SPEI12

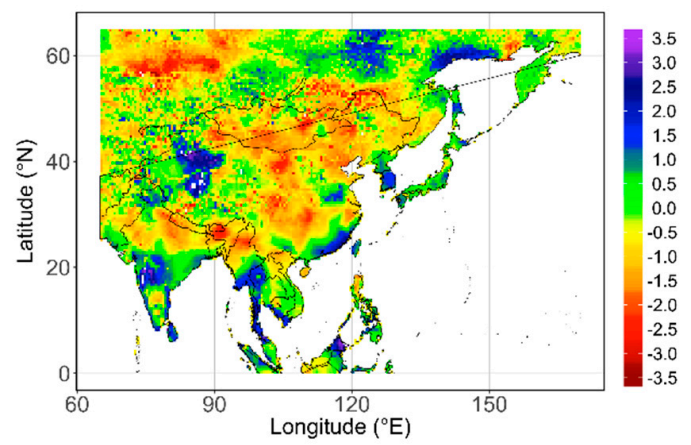

(b2) SRI12

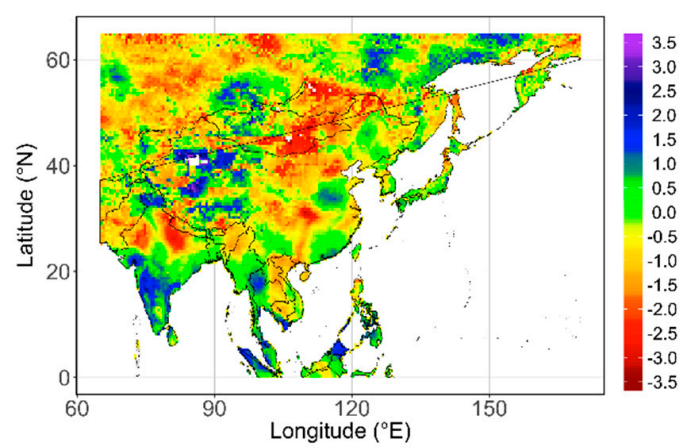

(b3) SSMI12

(b) CLM

(a) CRU

Figure 9. Spatial variations in three drought indices with 12-month lags (SPEI12, SRI12, and SSMI12) in 2009 in East Asia. 
SRI and SSMI by CLM also captured these drought distributions (Figure 9(b2,b3)), although there were some small differences in spatial patterns. CLM considers various physical theories (atmospheric circulation and runoff) and many input variables (precipitation, air temperature, topography, and soil characteristics) in the simulations of runoff and soil moisture. The variations in these inputs may generate the slight differences in spatial patterns in Figure 9.

We categorized three drought indices in Table 3 and Figure 10 and examined the drought characteristics (frequency and severity) in Figure 11. To clearly compare the three drought indices between CRU and CLM outputs, the grid resolutions in Figure 10 are generated with $5^{\circ}$ longitude $\times 5^{\circ}$ latitude. First, we counted the categorized drought events depending on the drought severity (Table 3), and then we calculated the regional averages of the categorized drought events depending on SPEI, SRI, SSMI, and CRU and CLM datasets.

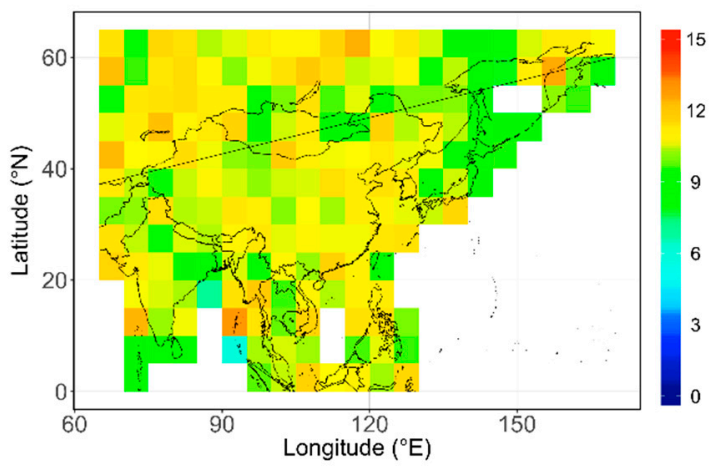

(a1) Frequency of D2 in SPEI12

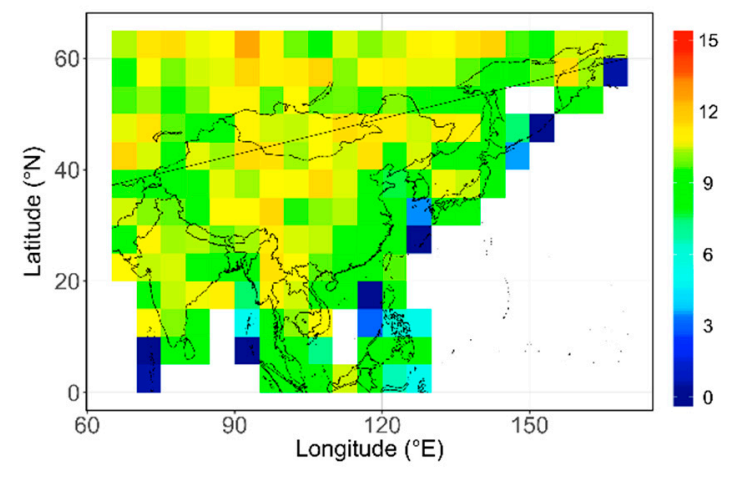

(b1) Frequency of D2 in SPEI12

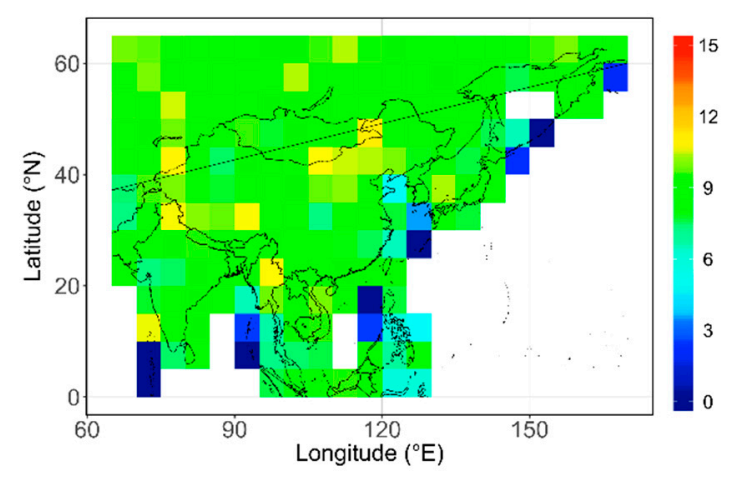

(b2) Frequency of D2 in SRI12

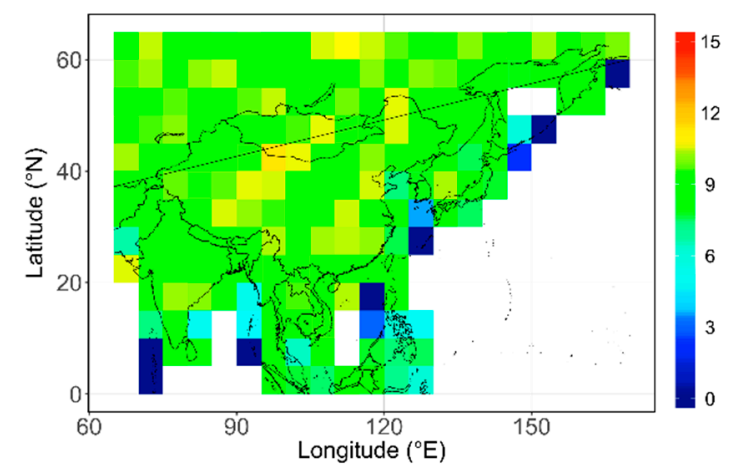

(b3) Frequency of D2 in SSMI12

(b) CLM

(a) CRU

Figure 10. Frequency of drought events in drought severity status 2 (D2) in Table 3 for 1951-2010. 
In Figure 10, the spatial D2 status (moderate dry) is shown for each drought index and dataset. For SPEI, the general spatial frequencies were similar to each other within the inland area regardless of whether the observations (CRU) or simulations (CLM) were used. However, the CLM simulations indicated lower frequencies than those by CRU for droughts near the coastal area. This may be one of the weaknesses of simulation models that only use land-surface data.

In Figure 11, we compared the drought frequencies for each drought index and dataset depending on the drought severity. For SPEI, three drought indices calculated using CRU and CLM data were compared to each other. From D1 to D4, the regional averages of drought frequencies by CRU and CLM are 30.02 and 31.13 for D1, 10.39 and 9.45 for D2, 3.97 and 3.62 for D3, and 0.83 and 0.79 for D4, respectively. For D1, the drought frequency in the CLM simulation showed the best match to that in the observation dataset (CRU), but the similarities between the drought frequencies of the observations and simulations became weaker as the droughts became more severe. For SRI, we compared the CLM drought indices based on the drought status. From D1 to D4, the regional averages of drought frequencies by CLM were $32.71,8.37,3.48$, and 1.24, respectively. For SSMI, from D1 to D4, the regional averages of drought frequencies by CLM were 31.43, 8.70, 3.76, and 1.50, respectively. These patterns may be affected by the differences in the simulated runoff and soil moisture values illustrated in Figures 5-8.

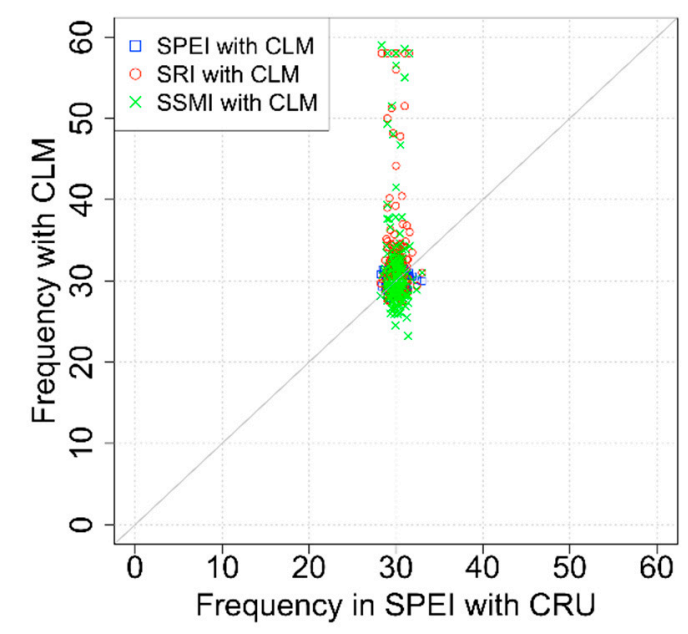

(a) D1

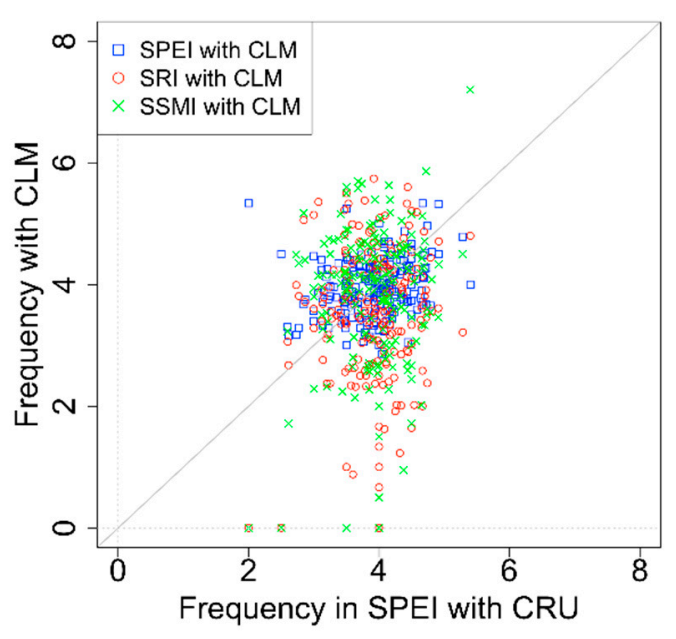

(c) D3

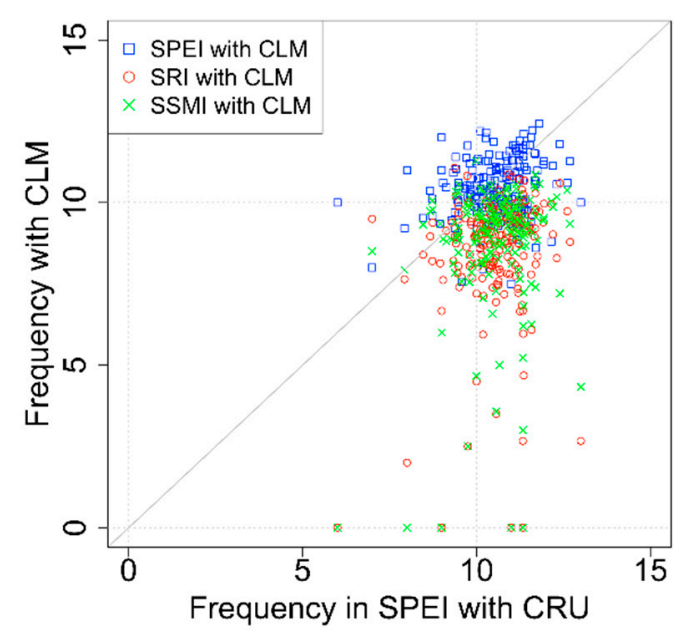

(b) D2

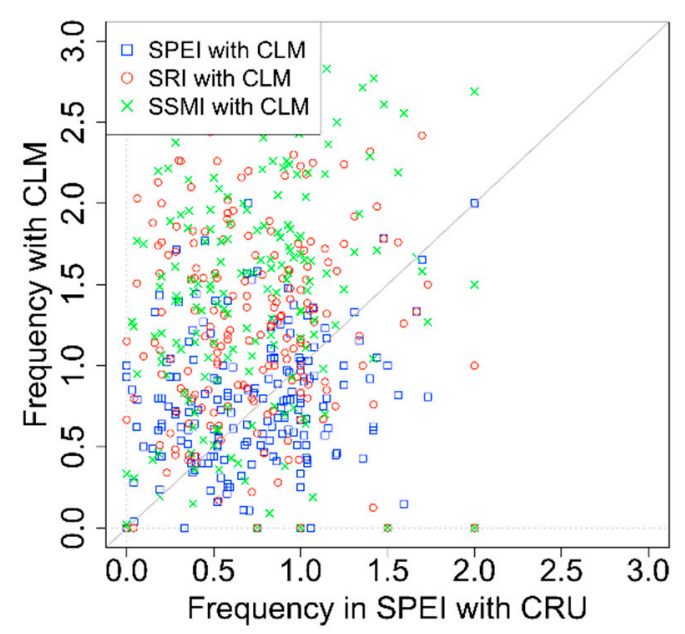

(d) D4

Figure 11. Comparisons of averaged drought frequencies depending on the drought severity with 5-deg gapped longitude and latitude for 1951-2010 in East Asia. 
Finally, we investigated the temporal patterns of three drought indices for CRU and CLM datasets for 1951-2010 in East Asia. The annual average movements of the three latitude-dependent drought indices are shown in Figure 12. We found very similar temporal patterns in the three SPEIs by CRU and CLM. For example, there are wet patterns between latitudes $35-60^{\circ}$ around the year 1960 and dry patterns between $0-25^{\circ}$ circa 1991 and $35-50^{\circ}$ circa 2009 . However, these temporal patterns slightly changed for the SRI and SSMI calculated by CLM. The spatial range and temporal periods in SRI and SSMI do not exactly match those in SPEI, likely because of the topography data and soil characteristics used in the simulation models. Nasrollahi et al. [2] and Um et al. [66] performed an analysis with the assumption of independent data. We also extracted independent data-the monthly drought index data from January to December of each year-and used it to analyze the characteristics of the droughts. However, in future studies, we will consider the time-lag among these three types of drought indices based on the big basin. The SSMIs calculated by CLM showed a broad range of dry statuses at 25-65 latitude in the final 6-7 years (2004-2010), although the spatial range and temporal periods of meteorological dry statuses in the CLM were in narrower ranges ( $35-50^{\circ}$ latitude) and shorter periods (2007-2010). We also analyzed the decadal temporal movements of drought frequencies based on seven drought indices and drought severity (Figure 13). For SPEI, temporal trends by CRU and CLM were similar to each other. For SRI, the simulation dataset had different temporal patterns because the runoff models of the CLM used different physical concepts presented in Table 2. For SSMI, the CLM showed very similar increasing trends, but the SSMI by CLM showed growing drought frequencies for D1 and D4 compared to the SPEI by CLM.

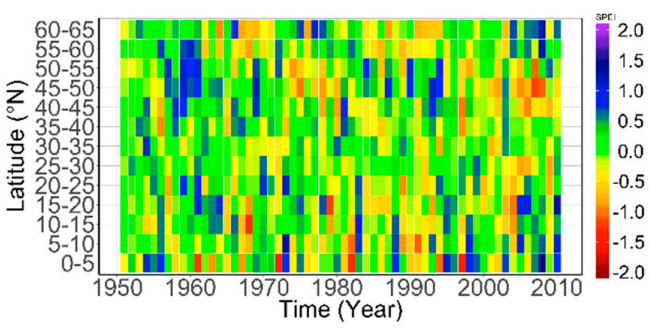

(a1) SPEI12

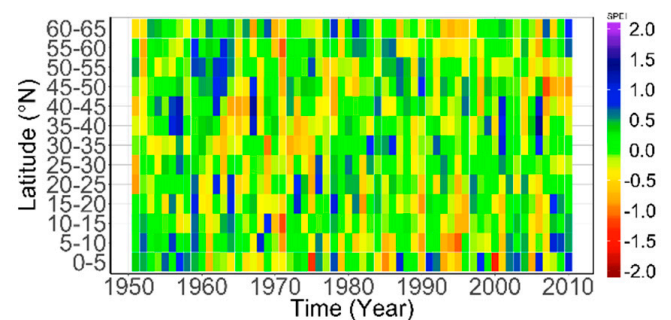

(b1) SPEI12

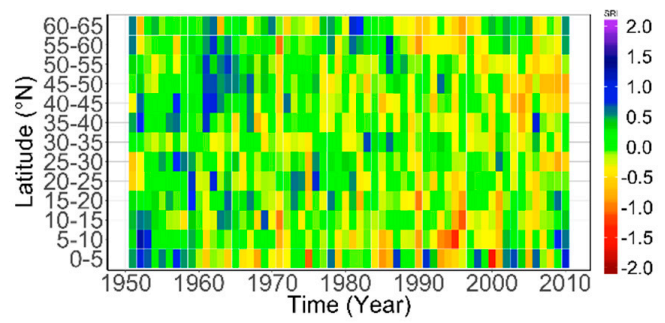

(b2) SRI12

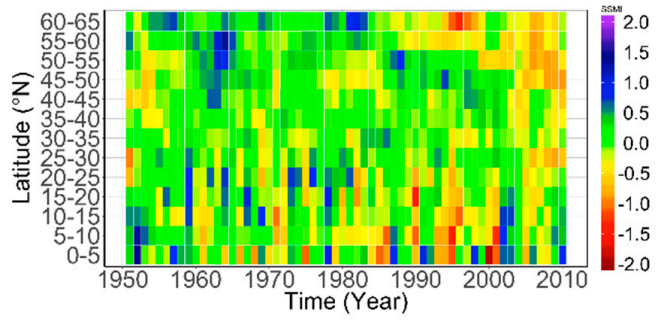

(b3) SSMI12

(b) CLM

(a) CRU

Figure 12. Temporal movements in three drought indices with 12-month lags (SPEI12, SRI12, and SSMI12) in East Asia. 


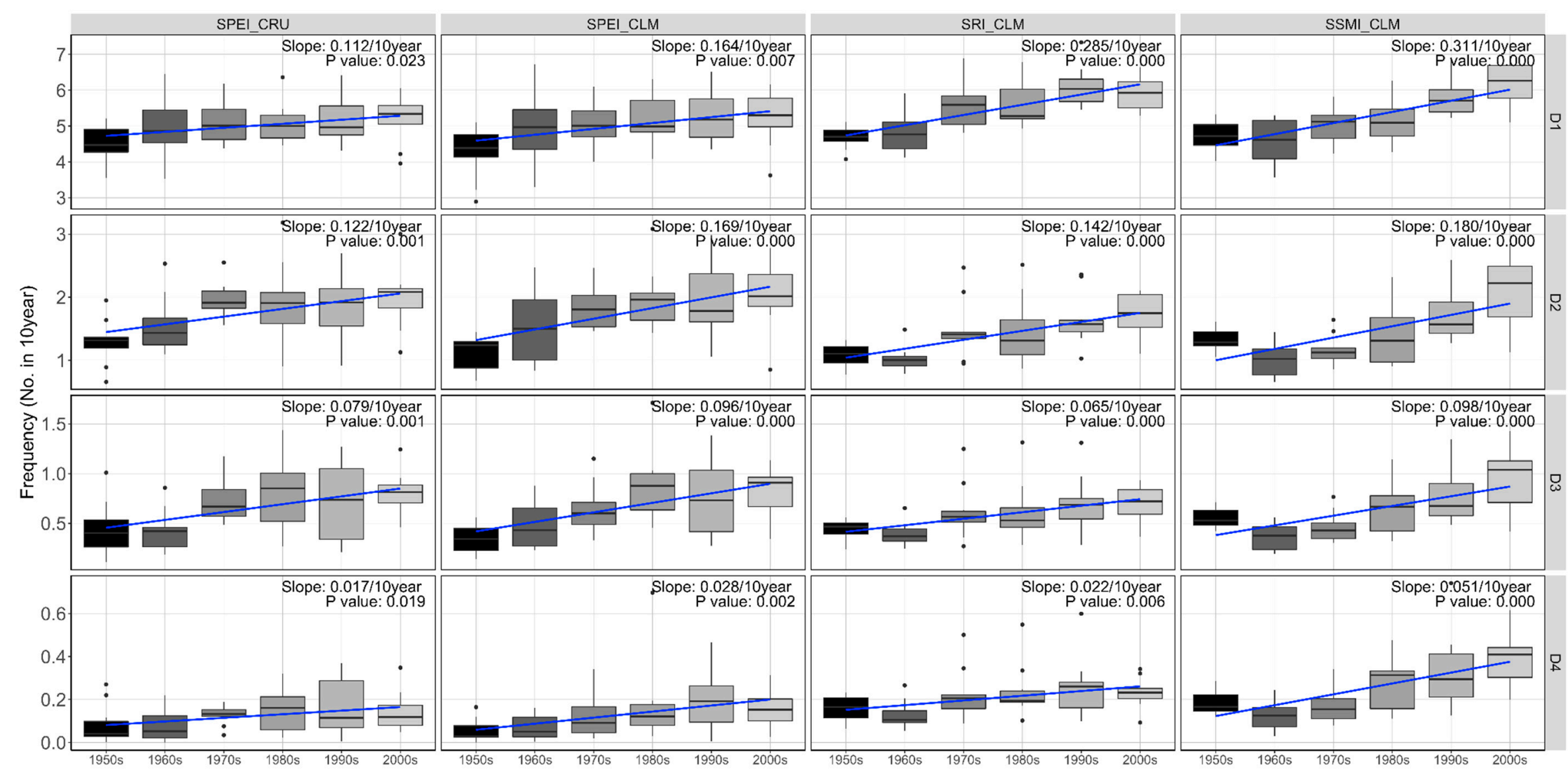

Figure 13. Temporal movements of drought frequencies depending on the drought severity for 1951-2010 in East Asia. 


\section{Conclusions}

This study investigated the applicability of CLM for drought evaluation compared to observed CRU data in East Asia. The CRU-NCEP data was used as CLM input data. We compared CRU data, with the CRU-NCEP dataset as the downscaled CLM input data, and showed that the annual precipitation and temperature data between the two datasets were spatially similar to each other. We generated the annual average and monthly potential evapotranspiration data with the CLM and compared them with the CRU datasets for East Asia. The estimated potential evaporation data in the CLM were higher than those in the CRU datasets. However, runoff variables in the CLM were spatially and temporally similar to the GRDC dataset (observations).

We compared SPEI with 12-month lags and the frequency of drought events for the CRU dataset and CLM outputs. The spatial results of the two datasets were similar. We then generated SRI and SSMI with 12-month lags and the frequency of drought events in each index. In addition, temporal movements in SPI12 in the CLM were verified by comparing them with the SPEI in CRU data. CLM provided temporal movement data in SRI12 and SSMI12. We also investigated the temporal movements of drought frequencies. SPEI with CLM had very similar drought frequency distributions to SPEI with CRU. All three drought indices (SPEI, SRI, and SSMI) in the CLM showed similar trends to the SPEI in CRU data. Theoretically, SPEI, SRI and SSMI differences by lag time occur based on hydrological circulation phenomenon. However, this study only investigated the differences in this lag time based on CLM. Therefore, it is necessary to confirm the exact differences among the three drought indices by using fully observed data.

We verified the CLM applicability to spatial and temporal drought analysis in East Asia. The results suggested that CLM can be a substitute model to investigate droughts in regions that do not have any observational hydroclimate data. For future work, the CLM should be further verified when observed hydroclimate variables like soil moisture are sufficient and applied to other regions in which (1) the observed hydroclimate data is insufficient to estimate the drought status and (2) the climate conditions are different from East Asia to confirm its applicability in drought analysis.

Author Contributions: M.-J.U. designed the study and performed the data analysis; Y.K. simulated the land surface model; M.M.K. and D.P. wrote the manuscript.

Acknowledgments: This research was supported by the Korea Agency for Infrastructure Technology Advancement (KAIA) grant funded by the Ministry of Land, Infrastructure, and Transport (Grant 18AWMPB083066-05), the Korea Meteorological Administration R\&D Program (Grant KMIPA 2015-6180), and a grant (2017-MOIS31-001) from the Fundamental Technology Development Program for Extreme Disaster Response funded by the Korean Ministry of Interior and Safety (MOIS).

Conflicts of Interest: The authors declare no conflict of interest.

\section{References}

1. Wilhite, D.A. Drought and Water Crises: Science, Technology, and Management Issues; CRC Press: Boca Raton, FL, USA, 2005.

2. Nasrollahi, N.; AghaKouchak, A.; Cheng, L.; Damberg, L.; Phillips, T.J.; Miao, C.; Hsu, K.; Sorooshian, S. How well do CMIP5 climate simulations replicate historical trends and patterns of meteorological droughts? Water Resour. Res. 2015, 51, 2847-2864. [CrossRef]

3. Xu, K.; Yang, D.; Yang, H.; Li, Z.; Qin, Y.; Shen, Y. Spatio-temporal variation of drought in china during 1961-2012: A climatic perspective. J. Hydrol. 2015, 526, 253-264. [CrossRef]

4. McKee, T.B.; Doesken, N.J.; Kleist, J. The relationship of drought frequency and duration to time scales. In Proceedings of the 8th Conference on Applied Climatology, Boston, MA, USA, 17-22 January 1993; pp. 179-183.

5. Edwards, D.C.; McKee, T.B. Characteristics of 20th century drought in the united states at multiple time scales. In Atmospheric Science Paper; Storming Media: Fort Collins, CO, USA, 1997.

6. Vicente-Serrano, S.M.; Beguería, S.; López-Moreno, J.I. A multiscalar drought index sensitive to global warming: The standardized precipitation evapotranspiration index. J. Clim. 2010, 23, 1696-1718. [CrossRef] 
7. Naumann, G.; Barbosa, P.; Garrote, L.; Iglesias, A.; Vogt, J. Exploring drought vulnerability in Africa: An indicator based analysis to be used in early warning systems. Hydrol. Earth Syst. Sci. 2014, 18, 1591-1604. [CrossRef]

8. Shukla, S.; Wood, A.W. Use of a standardized runoff index for characterizing hydrologic drought. Geophys. Res. Lett. 2008, 35. [CrossRef]

9. Wang, D.; Hejazi, M.; Cai, X.; Valocchi, A.J. Climate change impact on meteorological, agricultural, and hydrological drought in central Illinois. Water Resour. Res. 2011, 47. [CrossRef]

10. Leng, G.; Tang, Q.; Rayburg, S. Climate change impacts on meteorological, agricultural and hydrological droughts in china. Glob. Planet. Chang. 2015, 126, 23-34. [CrossRef]

11. Zhang, L.; Zhou, T. Drought over east Asia: A review. J. Clim. 2015, 28, 3375-3399. [CrossRef]

12. Wang, H.; He, S. The north china/northeastern Asia severe summer drought in 2014. J. Clim. 2015, 28, 6667-6681. [CrossRef]

13. Kwon, H.-H.; Lall, U.; Kim, S.-J. The unusual 2013-2015 drought in South Korea in the context of a multicentury precipitation record: Inferences from a nonstationary, multivariate, bayesian copula model. Geophys. Res. Lett. 2016, 43, 8534-8544. [CrossRef]

14. Wu, H.; Hayes, M.J.; Weiss, A.; Hu, Q. An evaluation of the standardized precipitation index, the china-z index and the statistical z-score. Int. J. Climatol. 2001, 21, 745-758. [CrossRef]

15. Zhai, J.; Su, B.; Krysanova, V.; Vetter, T.; Gao, C.; Jiang, T. Spatial variation and trends in PDSI and SPI indices and their relation to streamflow in 10 large regions of china. J. Clim. 2010, 23, 649-663. [CrossRef]

16. Hao, C.; Zhang, J.; Yao, F. Combination of multi-sensor remote sensing data for drought monitoring over southwest china. Int. J. Appl. Earth Obs. Geoinf. 2015, 35, 270-283. [CrossRef]

17. Wang, W.; Zhu, Y.; Xu, R.; Liu, J. Drought severity change in china during 1961-2012 indicated by SPI and SPEI. Nat. Hazards 2015, 75, 2437-2451. [CrossRef]

18. Tan, C.; Yang, J.; Li, M. Temporal-spatial variation of drought indicated by SPI and SPEI in Ningxia Hui autonomous region, China. Atmosphere 2015, 6, 1399-1421. [CrossRef]

19. Yu, M.; Li, Q.; Hayes, M.J.; Svoboda, M.D.; Heim, R.R. Are droughts becoming more frequent or severe in china based on the standardized precipitation evapotranspiration index: 1951-2010? Int. J. Climatol. 2014, 34, 545-558. [CrossRef]

20. Liu, Z.; Wang, Y.; Shao, M.; Jia, X.; Li, X. Spatiotemporal analysis of multiscalar drought characteristics across the loess plateau of China. J. Hydrol. 2016, 534, 281-299. [CrossRef]

21. Lee, B.-R.; Sung, J.H.; Chung, E.-S. Comparison of meteorological drought and hydrological drought index. J. Korea Water Resour. Assoc. 2015, 48, 69-78. [CrossRef]

22. Nam, W.-H.; Hayes, M.J.; Svoboda, M.D.; Tadesse, T.; Wilhite, D.A. Drought hazard assessment in the context of climate change for south Korea. Agric. Water Manag. 2015, 160, 106-117. [CrossRef]

23. Sohn, S.J.; Ahn, J.B.; Tam, C.Y. Six month-lead downscaling prediction of winter to spring drought in South Korea based on a multimodel ensemble. Geophys. Res. Lett. 2013, 40, 579-583. [CrossRef]

24. Park, J.; Lim, Y.-J.; Kim, B.-J.; Sung, J.H. Appraisal of drought characteristics of representative drought indices using meteorological variables. KSCE J. Civ. Eng. 2017, 22, 2002-2009. [CrossRef]

25. Min, S.K.; Kwon, W.T.; Park, E.-H.; Choi, Y. Spatial and temporal comparisons of droughts over Korea with east Asia. Int. J. Climatol. 2003, 23, 223-233. [CrossRef]

26. Um, M.-J.; Kim, Y.; Park, D. Evaluation and modification of the drought severity index (DSI) in east Asia. Remote Sens. Environ. 2018, 209, 66-76. [CrossRef]

27. Sacks, W.J.; Cook, B.I.; Buenning, N.; Levis, S.; Helkowski, J.H. Effects of global irrigation on the near-surface climate. Clim. Dyn. 2009, 33, 159-175. [CrossRef]

28. Lawrence, P.J.; Chase, T.N. Climate impacts of making evapotranspiration in the community land model (CLM3) consistent with the simple biosphere model (SIB). J. Hydrometeorol. 2009, 10, 374-394. [CrossRef]

29. Lawrence, P.J.; Chase, T.N. Investigating the climate impacts of global land cover change in the community climate system model. Int. J. Climatol. 2010, 30, 2066-2087. [CrossRef]

30. Jin, J.; Miller, N.L. Regional simulations to quantify land use change and irrigation impacts on hydroclimate in the California central valley. Theor. Appl. Climatol. 2011, 104, 429-442. [CrossRef]

31. Li, M.; Ma, Z. Comparisons of simulations of soil moisture variations in the yellow river basin driven by various atmospheric forcing data sets. Adv. Atmos. Sci. 2010, 27, 1289-1302. [CrossRef] 
32. Sakaguchi, K.; Zeng, X. Effects of soil wetness, plant litter, and under-canopy atmospheric stability on ground evaporation in the community land model (CLM3. 5). J. Geophys. Res. Atmos. 2009, 114. [CrossRef]

33. Lawrence, D.M.; Oleson, K.W.; Flanner, M.G.; Thornton, P.E.; Swenson, S.C.; Lawrence, P.J.; Zeng, X.; Yang, Z.L.; Levis, S.; Sakaguchi, K. Parameterization improvements and functional and structural advances in version 4 of the community land model. J. Adv. Model. Earth Syst. 2011, 3. [CrossRef]

34. Bonan, G.B.; Oleson, K.W.; Fisher, R.A.; Lasslop, G.; Reichstein, M. Reconciling leaf physiological traits and canopy flux data: Use of the try and fluxnet databases in the community land model version 4. J. Geophys. Res. Biogeosci. 2012, 117. [CrossRef]

35. Qin, Y.; Yang, D.; Lei, H.; Xu, K.; Xu, X. Comparative analysis of drought based on precipitation and soil moisture indices in Haihe basin of North China during the period of 1960-2010. J. Hydrol. 2015, 526, 55-67. [CrossRef]

36. Yang, Q.; Li, M.; Zheng, Z.; Ma, Z. Regional applicability of seven meteorological drought indices in china. Sci. China Earth Sci. 2017, 60, 745-760. [CrossRef]

37. Zhao, M.; Velicogna, I.; Kimball, J.S. A global gridded dataset of grace drought severity index for 2002-2014: Comparison with PDSI and SPEI and a case study of the Australia millennium drought. J. Hydrometeorol. 2017, 18, 2117-2129. [CrossRef]

38. Peterson, T.C.; Karl, T.R.; Jamason, P.F.; Knight, R.; Easterling, D.R. First difference method: Maximizing station density for the calculation of long-term global temperature change. J. Geophys. Res. Atmos. 1998, 103, 25967-25974. [CrossRef]

39. Harris, I.; Jones, P.; Osborn, T.; Lister, D. Updated high-resolution grids of monthly climatic observations-the CRU TS3. 10 dataset. Int. J. Climatol. 2014, 34, 623-642. [CrossRef]

40. Fekete, B.M.; Vörösmarty, C.J.; Grabs, W. High-resolution fields of global runoff combining observed river discharge and simulated water balances. Glob. Biogeochem. Cycles 2002, 16. [CrossRef]

41. Bonan, B. The Ncar Land Surface Model (Lsm Version 1.0) Coupled to the Ncar Community Climate Model; National Center for Atmospheric Research: Boulder, CO, USA, 1996.

42. Collins, W.D.; Bitz, C.M.; Blackmon, M.L.; Bonan, G.B.; Bretherton, C.S.; Carton, J.A.; Chang, P.; Doney, S.C.; Hack, J.J.; Henderson, T.B. The community climate system model version 3 (CCSM3). J. Clim. 2006, 19, 2122-2143. [CrossRef]

43. Gent, P.R.; Yeager, S.G.; Neale, R.B.; Levis, S.; Bailey, D.A. Improvements in a half degree atmosphere/land version of the CCSM. Clim. Dyn. 2010, 34, 819-833. [CrossRef]

44. Leung, L.R.; Kuo, Y.-H.; Tribbia, J. Research needs and directions of regional climate modeling using WRF and CCSM. Bull. Am. Meteorol. Soc. 2006, 87, 1747-1751. [CrossRef]

45. Bonan, G.B.; Lawrence, P.J.; Oleson, K.W.; Levis, S.; Jung, M.; Reichstein, M.; Lawrence, D.M.; Swenson, S.C. Improving canopy processes in the community land model version 4 (CLM4) using global flux fields empirically inferred from fluxnet data. J. Geophys. Res. Biogeosci. 2011, 116. [CrossRef]

46. Li, H.; Huang, M.; Wigmosta, M.S.; Ke, Y.; Coleman, A.M.; Leung, L.R.; Wang, A.; Ricciuto, D.M. Evaluating runoff simulations from the community land model 4.0 using observations from flux towers and a mountainous watershed. J. Geophys. Res. Atmos. 2011, 116. [CrossRef]

47. Zhang, Y.F.; Hoar, T.J.; Yang, Z.L.; Anderson, J.L.; Toure, A.M.; Rodell, M. Assimilation of MODIS snow cover through the data assimilation research testbed and the community land model version 4. J. Geophys. Res. Atmos. 2014, 119, 7091-7103. [CrossRef]

48. Lee, J.E.; Berry, J.A.; Tol, C.; Yang, X.; Guanter, L.; Damm, A.; Baker, I.; Frankenberg, C. Simulations of chlorophyll fluorescence incorporated into the community land model version 4. Glob. Chang. Biol. 2015, 21, 3469-3477. [CrossRef] [PubMed]

49. Beven, K. Topmodel: A critique. Hydrol. Process. 1997, 11, 1069-1085. [CrossRef]

50. Niu, G.Y.; Yang, Z.L.; Dickinson, R.E.; Gulden, L.E. A simple TOPMODEL-based runoff parameterization (simtop) for use in global climate models. J. Geophys. Res. Atmos. 2005, 110. [CrossRef]

51. Niu, G.Y.; Yang, Z.L.; Dickinson, R.E.; Gulden, L.E.; Su, H. Development of a simple groundwater model for use in climate models and evaluation with gravity recovery and climate experiment data. J. Geophys. Res. Atmos. 2007, 112. [CrossRef]

52. Lei, H.; Huang, M.; Leung, L.R.; Yang, D.; Shi, X.; Mao, J.; Hayes, D.J.; Schwalm, C.R.; Wei, Y.; Liu, S. Sensitivity of global terrestrial gross primary production to hydrologic states simulated by the community land model using two runoff parameterizations. J. Adv. Model. Earth Syst. 2014, 6, 658-679. [CrossRef] 
53. Tang, D.; Ma, C.; Wang, Y.; Xu, X. Multiscale evaluation of NCEP and CRUNCEP data sets at 90 large U.S. Cities. J. Geophys. Res. Atmos. 2017, 122, 7433-7444. [CrossRef]

54. McKee, T.B. In Drought monitoring with multiple time scales. In Proceedings of the 9th Conference on Applied Climatology, Boston, MA, USA, 15-20 January 1995.

55. Palmer, W.C. Meteorological Drought; Citeseer: Harrisburg, PA, USA, 1965; Volume 30.

56. Jacobi, J.; Perrone, D.; Duncan, L.L.; Hornberger, G. A tool for calculating the palmer drought indices. Water Resour. Res. 2013, 49, 6086-6089. [CrossRef]

57. Penman, H.L. Natural evaporation from open water, bare soil and grass. Proc. R. Soc. Lond. A 1948, 193, 120-145. [CrossRef]

58. Donohue, R.J.; McVicar, T.R.; Roderick, M.L. Assessing the ability of potential evaporation formulations to capture the dynamics in evaporative demand within a changing climate. J. Hydrol. 2010, 386, 186-197. [CrossRef]

59. Changnon, S.A. Detecting drought conditions in Illinois. In Circular 169; Department of Energy and Natural Resources: Champaign, IL, USA, 1987.

60. Wilks, D.S.; Eggleston, K.L. Estimating monthly and seasonal precipitation distributions using the 30-and 90-day outlooks. J. Clim. 1992, 5, 252-259. [CrossRef]

61. Wu, H.; Hayes, M.J.; Wilhite, D.A.; Svoboda, M.D. The effect of the length of record on the standardized precipitation index calculation. Int. J. Climatol. 2005, 25, 505-520. [CrossRef]

62. Robock, A.; Vinnikov, K.Y.; Srinivasan, G.; Entin, J.K.; Hollinger, S.E.; Speranskaya, N.A.; Liu, S.; Namkhai, A. The global soil moisture data bank. Bull. Am. Meteorol. Soc. 2000, 81, 1281-1299. [CrossRef]

63. Dorigo, W.; Wagner, W.; Hohensinn, R.; Hahn, S.; Paulik, C.; Xaver, A.; Gruber, A.; Drusch, M.; Mecklenburg, S.; Oevelen, P.V. The international soil moisture network: A data hosting facility for global in situ soil moisture measurements. Hydrol. Earth Syst. Sci. 2011, 15, 1675-1698. [CrossRef]

64. Dorigo, W.; Xaver, A.; Vreugdenhil, M.; Gruber, A.; Hegyiova, A.; Sanchis-Dufau, A.; Zamojski, D.; Cordes, C.; Wagner, W.; Drusch, M. Global automated quality control of in situ soil moisture data from the international soil moisture network. Vadose Zone J. 2013, 12. [CrossRef]

65. Qiu, J. China Drought Highlights Future Climate Threats; Nature Publishing Group: London, UK, 2010.

66. Um, M.-J.; Kim, Y.; Kim, J. Evaluating historical drought characteristics simulated in CORDEX East Asia against observation. Int. J. Climatol. 2017, 37, 4643-4655. [CrossRef] 